\title{
Implementation of IFRS 9 for Banking in Indonesia
}

\begin{abstract}
Phe Lie and Erman Sumirat, SE, M. Bus, AK, School of Business and Management Institut Teknologi Bandung, Indonesia

Abstract: Banking is a highly regulated industry with a lot of changes in its business environment. Basel, IASB, BI/OJK, IAI, and other Regulators are stipulating Bank's standard capital, operation, business and portfolio, financial and accounting, and reporting in order Bank could survive the global economic changes and grow healthier in a fierce competition. This research raises the regulatory changes in financial instruments from IAS 39 into IFRS 9 with major changes in simplification of classification and measurement, moving from incurred loss to expected loss model and improved the hedge accounting model to address Bank's capital issue as one of the major requirements to keep Banks soundness with sufficient allowance for impairment losses. The research in one of the Bank in Indonesia has performed the gap analysis between impairment under IAS 39 and IFRS 9 resulted in the model of impairment under IFRS 9: ECL formula and time framework, macroeconomics variables as forward looking calibration for PD/LGD, disclosure and risk governance. The impacts of IFRS 9 implementation is higher allowance that as one of Bank's expenses, would lower Bank's earning and lower the capital accordingly. Higher allowance decrease credit RWA but impacted to better composition of CAR, that should there be any event of default, Bank has enough allowance to cover the losses instead of using their capital. The better composition of CAR improves Bank's soundness and comply with the Regulation and able to reflect the fair value of Bank's asset impairment.
\end{abstract}

Keywords: IFRS 9, PSAK 71, Expected Credit Loss, Impairment, Allowance for Impairment Losses

\section{Introduction}

Bank collects funds from the public in the form of savings and distributes it again in the form of credit and or other forms. Bank shall always maintain its level of soundness in order to be beneficial for the nation's economic perspective. According to Laws of the Republic Indonesia number 10 year 1998 about amendment to Laws number 7 year 1992 about Banking, Commercial Banks are required to maintaining soundness in accordance with the provisions of capital adequacy, asset quality, quality management, liquidity, profitability, solvency, and other aspects related to the business Banks, and shall conduct business activities in accordance with the principles of prudence.

When the external and internal environments of banking sector are experiencing rapid growth, this would be followed by the increasing complexity of risk for banking business activities. Hence, it is necessary to improve good governance practices as well as the identification, measurement, monitoring and risk control functions of banks. Financial Services Authority (OJK) establish regulation number 18/POJK.03/2016 concerning the Implementation of Risk Management for Commercial Banks to improve the governance function to maintain the soundness of Banks in Indonesia.

Under Bank Indonesia Regulation (PBI) number 14/15/PBI/2012 concerning Assessment of Commercial Bank Asset Quality, Bank is obliged to calculate Provision for Asset Losses (PPA) and Allowance for Impairment Losses (CKPN).

- PPA is a reserve that has to be calculated for a certain percentage based on asset quality. 
- $\mathrm{CKPN}$ is a reserve established in case the recorded value of financial assets shall be less than the originally recorded value after impairment.

Bank is obliged to book CKPN in accordance with prevailing financial accounting standards. CKPN is recorded in Bank financial reports in accordance to SE BI Number 15/28/DPNP dated 31 July 2013 about Assessment of Commercial Bank Asset Quality, number VIII. Provision for Asset Losses (PPA) and Allowance for Impairment Losses (CKPN).

PPA and CKPN are vital to Banks as it would impact Bank's Capital Adequacy Ratio (CAR) as the regulation stated that if the PPA calculation on Earning Assets is larger than the CKPN established, Bank is obliged to calculate the difference between PPA and CKPN as a reduction in capital in the calculation of CAR. If most Banks in one nation fail to maintain its CAR, it would affect the national's economic and national's financial rating.

The objective of the research is that Banks in Indonesia would comply with the regulatory requirement and accounting standard regarding the CKPN. Currently International Accountancy Standard (IAS) 39 or Pedoman Standar Akuntansi Keuangan (PSAK) 55 in Indonesia is the guiding standard to calculate the CKPN for its financial instruments. Some Banks have decided to apply the IFRS 9 in its asset impairment calculation starting 1 January 2018 following IFRS 9 global implementation even though OJK, BI, DAI and IAI have decided that PSAK 71 Instrumen Keuangan, Indonesian version of IFRS 9, will be effective in Indonesia starting 1 January 2020.

\section{Methods}

Research is conducted through gap analysis between the current practice under IAS 39 and future requirements under IFRS 9 in 3 (three) areas required by IFRS 9: 1) Classification and Measurement, 2) Impairment and 3) Hedge Accounting.

\subsection{Classification and Measurement}

Classification of the financial instruments under IAS 39 and according to IFRS 9 implementation would be based on business model and contractual cash flow characteristics to be measured as amortized cost and fair value through profit and loss or fair value through other comprehensive income. The comparison of classification and measurement of financial assets between current practice under IAS 39 and future requirement under IFRS 9 as shown in this below figure.
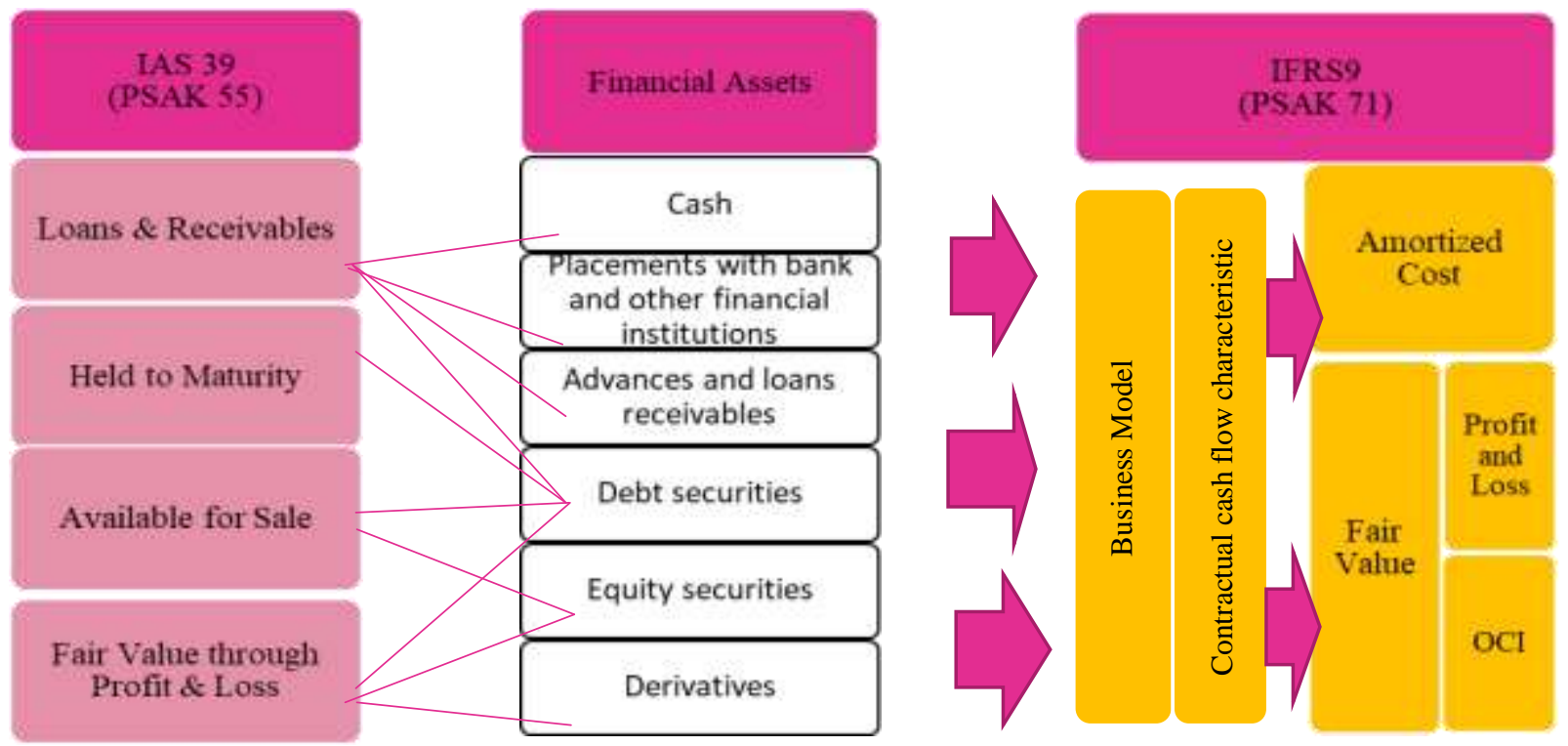

Fig. 1: Classification and Measurement of financial asset in IAS 39 and IFRS 9 


\subsection{Impairment}

The calculation of Expected Loss under IAS 39 / PSAK 55 would use below formula:

$$
\mathrm{EL}=\mathrm{PD} \times \mathrm{LGD} X \mathrm{XIP} \times \mathrm{EAD}
$$

- PD or Probability of Default is an estimate of the likelihood that the default event will occur. PD is estimated through an assessment of risk management framework over a particular time horizon. To estimate PD, historical data is of minimum 3 (three) consecutive years is needed.

- LGD or Loss Given Default is the share of an asset that is lost when a borrower defaults. The recovery rate is defined as 1 minus the LGD, the share of an asset that is recovered when a borrower defaults. The time horizon to estimate LGD is minimum at the same period with PD for the aspect of balance.

- LIP or Loss Identification Period is a factor in calculating the deteriorating in portfolio value in accordance with IAS / IFRS and calculation of "losses incurred". Under IAS 39, the LIP is mostly using 1 (one) year period of identification.

- EAD or Exposure at Default is an estimation of the extent to which a bank may be exposed to a counterparty in the event of, and at the time of, that counterparty's default.

The calculation of Expected Credit Loss (ECL) under IFRS 9 is more or less the same with EL under IAS 39. The difference is that 1) under IFRS 9, the ECL is calculated at point-in-time of PD / LGD / EAD and times to $\mathrm{D}$, which stands for discount rate at point-in-time, 2) the introduction of stage 2 - significant increase of credit risk, and 3) the forward looking calibration by using macroeconomic variables. The formula under IFRS 9 would be:

$$
E C L=\sum_{r=1}^{T}\left[P D_{t} \times L G D_{t} \times E A_{1} \times D_{t}\right]
$$

The IFRS 9 implementation - ECL recognition model have following criteria:

- Stage 1: 12 month expected losses are recognized at initial recognition

- Stage $2 \&$ 3: life time expected credit losses are recognized when there are significant increases of credit risk

- Interest accrual: gross for stages $1 \& 2$ and net for stage 3

- A wider range of information is allowed: past, present, and future

- Reasonable and supportable information without undue cost and effort

- Judgement needed

The difference between impairment under IAS 39 and IFRS 9 is seen on the stages of loss according to IAS 39 and IFRS 9, with the major difference is in stage 2 - significant increase in credit risk where the loss is moving from "incurred loss" into "expected loss".
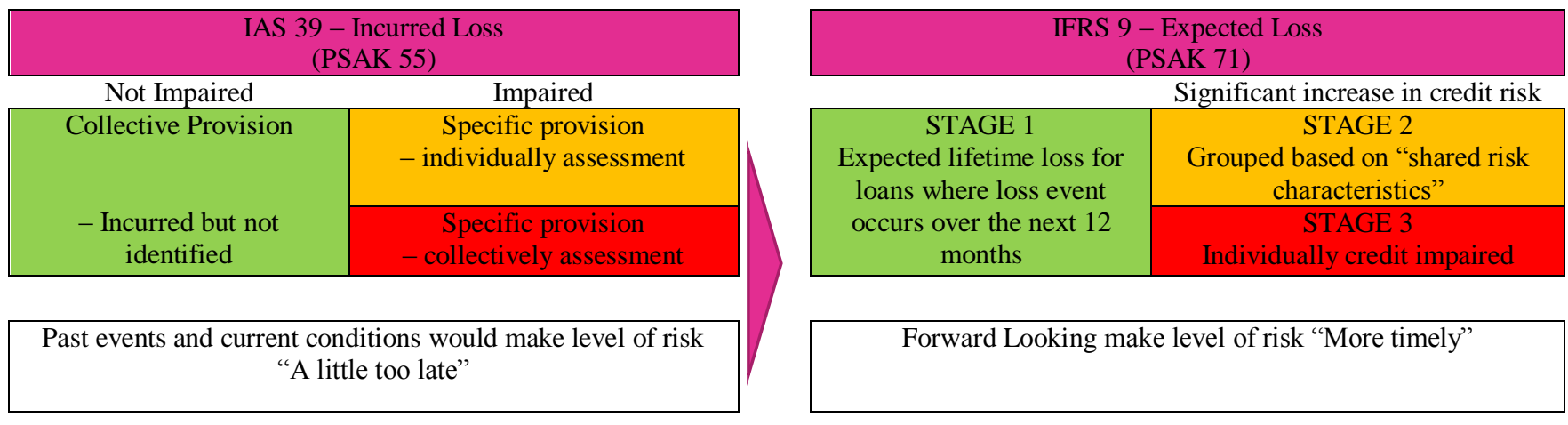

Fig. 2: Stages of Impairment Loss in IAS 39 and IFRS 9 
IFRS 9 explain that estimates of changes in expected credit loss should reflect, and be directionally consistent with changes in related observable data from period to period. [IFRS 9.B5.5.52] As losses are provisioned based on a forward looking basis instead of an incurred basis, ECL shall reflect:

a. The best available information including information about the past events, current conditions and reasonable and supportable forecasts of future events and economic conditions at the reporting date

b. An unbiased and probability-weighted estimate of cash flows associated with a range of possible outcomes (including at least the possibility that a credit lost occurs and the possibility that no credit loss occurs)

c. The time value of money

Hence macroeconomic variables as the forward looking calibration for ECL must be from the observable data, such as Inflation Rate (IR), Unemployment Rate (UR), Gross Domestic Bruto (GDP), Consumer Price Index (CPI), Housing Price Index (HPI), Money Supply, BI Rate, BI USD/IDR Exchange rate, Oil price, Commodity prices, etc.

\section{Results and Discussion}

The impact to Banks with the IFRS 9 implementation would be into 4 (four) major areas in Banks, yet in this research, author will only focus on the impact to risk and finance.

1. Risk and Finance; methodology and factors would be implemented in order to meet the regulatory requirements, and the impact of the changes in methodology and factors to Bank Financial Report to Supervisor and Group.

2. Business; the changing in allowance amount resulted from the IFRS 9 implementation would impact to Bank Profit and Loss Report and certainly would need business consideration to change the Bank pricing policy.

3. Governance; Bank's risk management framework that Bank should stipulate the changes in Bank Policy and Procedure.

4. Infrastructure; system that is needed to support the implementation to run in proper way and would need as least manual as possible to avoid human error in calculating and generating the Bank Financial Report.

\subsection{The Impact of IFRS 9 Implementation to Bank's Amount of ECL / CKPN}

The impact of IFRS 9 implementation in one sample of Bank could be seen from the additional amount for CKPN calculated by the suggested model compare to the amount of CKPN booked currently, the forecasted CKPN under IFRS 9 would be increased as much as IDR 12.521Bio (IDR 9.452 Bio from Loan and IDR 3.069 Bio from other asset) or $38.72 \%$ higher than current calculation under IAS 39 as follow:

TABLE I: Expected Credit Loss in IAS 39 and IFRS 9

\begin{tabular}{|c|c|c|c|c|}
\hline \multicolumn{2}{|r|}{ Financial Assets } & Impairment IAS39 by product (IDR) & ECL IFRS9 by product (IDR) & Difference \\
\hline \multirow{5}{*}{ Loan } & Loan Receivable (Principal) & 27.897 .672 .947 & 36.091 .552 .410 & 8.193 .879 .463 \\
\hline & Loan Receivable (Accrued interest) & - & 71.154 .610 & 71.154 .610 \\
\hline & Unused Commitment & - & 787.008 .937 & 787.008 .937 \\
\hline & RSME-Loan Receivable (principal) & 1.403 .492 .848 & 1.800 .658 .038 & 397.165 .190 \\
\hline & RSME-Loan Receivable (accrued interest & - & 2.510 .227 & 2.510 .227 \\
\hline \multirow{6}{*}{$\begin{array}{c}\text { Other } \\
\text { Financial } \\
\text { Assets }\end{array}$} & Acceptance receivable & 3.036 .000 .191 & 2.270 .991 .141 & $(765.009 .051)$ \\
\hline & Bank Guarantee & - & 163.277.406 & 163.277.406 \\
\hline & Financial Guarantee & - & 153.188 .949 & 153.188 .949 \\
\hline & Interbank Lending (principal) & - & 3.498 .329 .856 & 3.498 .329 .856 \\
\hline & Interbank Lending (accrued interest) & - & 19.669 .117 & 19.669 .117 \\
\hline & Investment & - & - & - \\
\hline \multicolumn{2}{|l|}{ Total } & 32.337.165.987 & 44.858.340.693 & \\
\hline \multicolumn{4}{|c|}{ Difference Total ECL / CKPN in amount } & 12.521.174.706 \\
\hline \multicolumn{4}{|c|}{ Difference ECL in \% } & $38,72 \%$ \\
\hline
\end{tabular}




\subsection{The Impact of IFRS 9 Implementation to Bank's Earnings}

The impact of IFRS 9 implementation to Bank's earning could be seen from below Income Statement Report for period of 1 January until 31 December 2016. The difference will be in item B. Operating Revenues and Expenses other than Interest, section 2. Operating Expenses other than Interest, sub-section e. Impairment loss on financial assets: current CKPN as much as IDR 159,599 Bio added to additional forecasted CKPN as much as IDR 12.521 Bio equal to total CKPN as much as IDR 172,120 Bio. The operating revenue shall increase, while the total operating income followed by the total current year comprehensive income shall also decrease accordingly.

TABLE II: Impact of IFRS 9 Implementation to Bank's Operational expenses and Operational Income

\begin{tabular}{|c|c|c|c|}
\hline No. & ITEMS & IAS 39 & IFRS 9 \\
\hline \multicolumn{4}{|c|}{ OPERATING REVENUES AND EXPENSES } \\
\hline \multicolumn{4}{|c|}{ A. Interest Revenue and Expense } \\
\hline \multicolumn{4}{|c|}{ B. Operating Revenues and Expenses other than Interest } \\
\hline 1. & Operating Revenues other than Interest & 784.173 & 784.173 \\
\hline \multirow[t]{8}{*}{2.} & Operating expenses other than Interest & $\mathbf{1 . 1 5 6 . 5 0 0}$ & 1.169 .021 \\
\hline & e. Impairment loss on financial assets & 159.599 & 172.120 \\
\hline & i. $\quad$ Securities & 0 & 0 \\
\hline & \begin{tabular}{|l|l|} 
ii. & Loans \\
\end{tabular} & 157.873 & 167.325 \\
\hline & \begin{tabular}{|l|l|} 
iii. & Sharia financing \\
\end{tabular} & 0 & 0 \\
\hline & \begin{tabular}{|l|l|} 
iv. & Other financial assets \\
\end{tabular} & 1.726 & 4.795 \\
\hline & Operating Revenues and Expenses other than Interest - Net & (372.327) & (384.848) \\
\hline & OPERATING INCOME (EXPENSE) & 186.369 & $\mathbf{1 7 3 . 8 4 8}$ \\
\hline \multicolumn{2}{|r|}{ TOTAL - CURRENT YEAR COMPREHENSIVE INCOME } & 143.283 & 130.762 \\
\hline
\end{tabular}

\subsection{The Impact of IFRS 9 Implementation to Banks's CAR}

The impact of IFRS 9 implementation to Bank's CAR could be seen from below Form 9.1. - Perhitungan Rasio Kewajiban Penyediaan Modal Minimum (KPMM) / Form 9.1. - Capital Adequacy Ratio (CAR) Calculation calculated based on Basel III requirement for year 2016. The difference will be in item 1. Total Aktiva Tertimbang Menurut Risiko (ATMR) untuk Risiko Kredit (sesuai ketentuan yang berlaku mengenai KPMM)* / 1. Total Risk Weighted Asset (RWA) for Credit Risk (in accordance with regulation concerning $R W A$ )*: Based on SE BI number 13/6/DPNP Jakarta, 18 February 2011, concerning Pedoman Perhitungan Aset Tertimbang Menurut Risiko untuk Risiko Kredit dengan Menggunakan Pendekatan Standar / Guideline to Calculate Risk Weighted Asset for Credit Risk under Standardize Approach, the ATMR for Credit Risk is calculated from the total Exposure of Credit subtracted to PPA / CKPN / ECL. Current RWA as much as IDR 7,657,356 Mio shall be subtracted by forecasted CKPN as much as IDR 12,521 Mio equal to total RWA as much as IDR 7,644,834 Mio. Hence, the ATMR for Credit Risk under IFRS 9 will be lower than ATMR for Credit Risk under IAS 39. Total capital is also decreased accordingly to the decrease of total comprehensive income.

TABLE III: Impact of IFRS 9 implementation to Bank's Risk Weighted Asset and Capital Adequacy Ratio

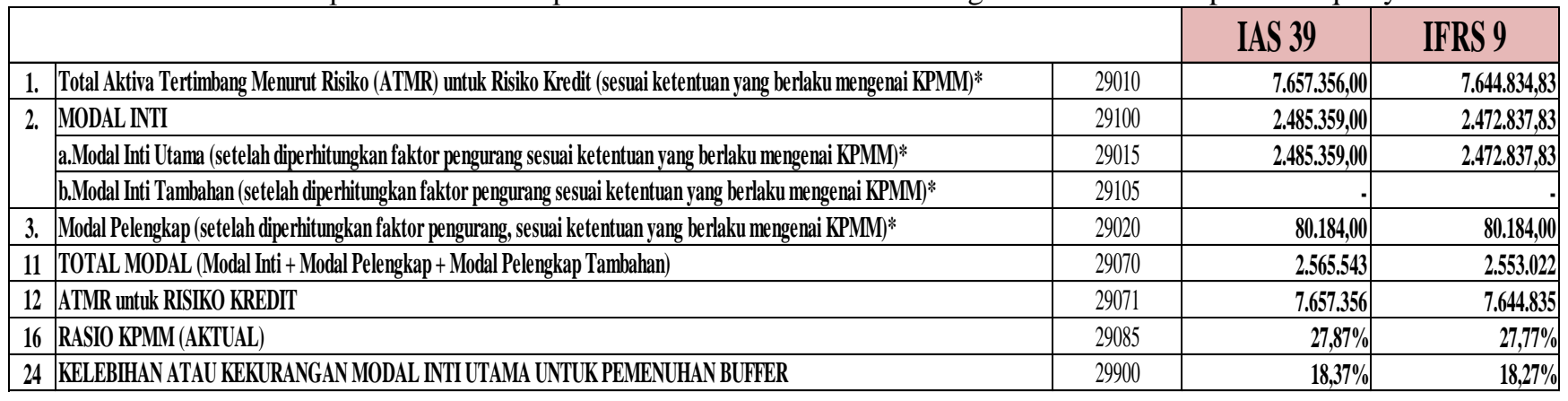




\section{Conclusions}

Under IFRS 9 implementation, the definition of credit loss moves from incurred loss into expected loss, while life time expected credit losses are recognized when there are significant increases of credit risk (even when the account is still categorized as performing loans). The purpose of IFRS 9 implementation is for capital adequacy assessment to comply with the Accounting Standard. Its philosophy is neutrality and principal based using one model impairment to recognize the impairment loss by using the tools of forward looking calibration for PD / LGD. The classification and measurement of financial instruments / assets are based on business model and nature of cash flows, while the reclassification could be conducted driven by those business model.

IFRS 9 implementation would impact Bank's CKPN, Earnings and KPMM / CAR. Most likely Bank would book higher CKPN under IFRS 9 implementation rather than under IAS 39. Bank's earnings will be lower as CKPN would be included as operating expenses of Bank. Bank's CAR would be lower yet better as Bank has had enough allowance that credit risk would not be covered by Bank's capital, but from the allowance that has been booked. By implementing IFRS 9 for impairment losses, Bank would have enough capital as required by Regulator.

\section{References}

[1] Bank Indonesia Regulation number 14/15/PBI/2012 and Circular Letter number 15/28/DPNP dated 31 July 2013 concerning Assessment of Commercial Bank Asset Quality

[2] Bank Indonesia Circular Letter number 13/6/DPNP Jakarta, 18 February 2011, concerning Guideline to Calculate Risk Weighted Asset for Credit Risk under Standardize Approach: Form 9.1. Laporan Bank Umum - Perhitungan Rasio Kewajiban Penyediaan Modal Minimum

[3] Gaston, E., 2016, Forward-Looking Credit Loss Recognition-IFRS 9 \& Related Developments and Supervisory Roles. FED-IMF-WB Seminar for Senior Bank Supervisors from Emerging Economies, 3 - 6, 8, 10 - 14.

[4] Hoesada, Dr. J., 2017, IFRS 9 Implementation Agenda. OJK Finance, Risk and Reporting Summit 2017 - OJK Audit Board.

[5] Ikatan Akuntan Indonesia, PSAK 50 Instrumen Keuangan: Penyajian

[6] Ikatan Akuntan Indonesia, PSAK 55 Instrumen Keuangan: Pengakuan dan Pengukuran

[7] Ikatan Akuntan Indonesia, Exposure Draft PSAK 71 Instrumen Keuangan

[8] International Accountant Standard Board, IAS 39 Financial Instrument

[9] International Accountant Standard Board, IFRS 9 Financial Instrument

[10] Laws of Republic Indonesia number 9 year 2016 dated 15 April 2016 about An Act of Prevention and Handling the Financial System Crisis

[11] Laws of the Republic Indonesia number 10 year 1998 about amendment to Laws number 7 year 1992 about Banking

[12] Osman Bing Satrio \& Eny, 2016, Deloitte - OJK Working Group: IFRS 9 Impairment Calculation.

[13] Otoritas Jasa Keuangan Regulation number 18/POJK.03/2016 concerning the Implementation of Risk Management for Commercial Banks

[14] Ruud, J. A., Näs, J. and Tortorici, V., 2007, Perspectives on Corporate Finance and Strategy. McKinsey on Finance, 24: $1-5$.

[15] Tanudiredja, Wibisana, Rintis \& Rekan, 2016, PSAK 50 \& PSAK 55.

[16] Tanudiredja, Wibisana, Rintis \& Rekan, 2016, Implementation of IFRS 9.

[17] Temenos, 2016, IAS 39 \& IFRS 9. 